\title{
Oregano essential oil-pectin edible films as anti-quorum sensing and food antimicrobial agents
}

\section{Maria V. Alvarez' Luis A. Ortega-Ramirez ${ }^{2}$, M. Melissa Gutierrez-Pacheco ${ }^{2}$, A. Thalia Bernal-Mercado ${ }^{2}$, Isela Rodriguez-Garcia ${ }^{2}$, Gustavo A. Gonzalez-Aguilar ${ }^{2}$, Alejandra Ponce ${ }^{1}$, Maria del R. Moreira ${ }^{1}$, Sara I. Roura ${ }^{1}$ and J. Fernando Ayala-Zavala ${ }^{2} *$}

\author{
Consejo Nacional de Investigaciones Científicas y Técnicas - Grupo de Investigación en Ingeniería en Alimentos, Facultad de Ingeniería, Universidad Nacional \\ de Mar del Plata, Mar del Plata, Argentina \\ ${ }^{2}$ Laboratorio de Tecnologías Emergentes, Coordinación de Tecnología de Alimentos de Origen Vegetal, Centro de Investigación en Alimentación y Desarrollo, \\ Hermosillo, México
}

\section{Edited by:}

Filomena Nazzaro, National Research Council - Institute of Food Science, Italy

\section{Reviewed by:}

Filomena Nazzaro, National Research Council - Institute of Food Science, Italy

Florinda Fratianni, National Research Council - Institute of Food Science, Italy

Maria Raquel Alcantara Miranda, Universidade Federal do Ceará, Brazil

${ }^{*}$ Correspondence:

J. Fernando Ayala-Zavala, Laboratorio de Tecnologías Emergentes,

Coordinación de Tecnología de Alimentos de Origen Vegetal, Centro de Investigación en Alimentación y Desarrollo, Hermosillo 83000, Sonora, México

e-mail: jayala@ciad.mx
Edible films can be used as carriers for antimicrobial compounds to assure food safety and quality; in addition, pathogenesis of food bacteria is related to a cell to cell communication mechanism called quorum sensing (OS). Oregano essential oil (OEO) has proved to be useful as food antimicrobial; however, its food applications can be compromised by the volatile character of its active constituents. Therefore, formulation of edible films containing OEO can be an alternative to improve its food usages. QS inhibitory activity of OEO and pectin-OEO films was evaluated using Chromobacterium violaceum as bacterial model. Additionally, antibacterial activity was tested against Escherichia coli 0157:H7, Salmonella Choleraesuis, Staphylococcus aureus, and Listeria monocytogenes. OEO was effective to inhibit bacterial growth at MIC of $0.24 \mathrm{mg} / \mathrm{mL}$ for all tested bacteria and MBC of 0.24 , $0.24,0.48$, and $0.24 \mathrm{mg} / \mathrm{mL}$ against E. coli $0157: \mathrm{H} 7, S$. Choleraesuis, S. aureus, and L. monocytogenes, respectively. Pectin-films incorporated with 36.1 and $25.9 \mathrm{mg} / \mathrm{mL}$ of OEO showed inhibition diameters of 16.3 and $15.2 \mathrm{~mm}$ for E. coli $\mathrm{O} 157: \mathrm{H7} ; 18.1$ and $24.2 \mathrm{~mm}$ for S. Choleraesuis; 20.8 and $20.3 \mathrm{~mm}$ for $S$. aureus; 21.3 and $19.3 \mathrm{~mm}$ for L. monocytogenes, respectively. Pectin-OEO film $(15.7 \mathrm{mg} / \mathrm{mL})$ was effective against $E$. coli $\mathrm{O} 157: \mathrm{H7}(9.3 \mathrm{~mm})$, S. aureus $(9.7 \mathrm{~mm})$, and $L$. monocytogenes $(9.2 \mathrm{~mm})$, but not for $S$. Choleraesuis. All concentrations of OEO $(0.0156,0.0312,0.0625$ and $0.125 \mathrm{mg} / \mathrm{mL})$ and pectin-OEO films $(15.7,25.9$ and $36.1 \mathrm{mg} / \mathrm{mL}$ ) showed a significant anti-OS activity expressed as inhibition of violacein production by $C$. violaceum. Additionally, the application of pectin-OEO films was effective reducing total coliforms, yeast, and molds of shrimp and cucumber slices stored at $4^{\circ} \mathrm{C}$ during $15 \mathrm{~d}$. These results demonstrated the potential of pectin films enriched with OEO as food related microorganisms and QS inhibitors.

Keywords: Chromobacterium violaceum, food safety, natural compounds, edible coatings, cell communication

\section{INTRODUCTION}

Despite advances in food safety, foodborne illness remains common around the world; in the United States more than 9 million people each year have suffer foodborne diseases caused by major pathogens: Escherichia coli O157:H7, Salmonella, Campylobacter, and Listeria monocytogenes (Scallan et al., 2011; CDC, 2014). The resistance and pathogenesis of these bacteria could be related to intercellular communication mechanisms like quorum sensing (QS), which is based on the synthesis, exchange and perception of small signaling molecules at given cellular densities (Dong and Zhang, 2005; Alvarez et al., 2012). This mechanisms allow Gram (+) and Gram (-) bacteria to regulate some physiological activities, such as virulence, competition amongst populations, conjugation, antibiotic production, motility, sporulation, and biofilm formation (Miller and Bassler, 2001; Truchado et al., 2012; Nazzaro et al., 2013). It has been hypothesized a regulation of food bacterial proliferation by QS, and its inhibition could be a good strategy to assure food safety and quality (Rasch et al., 2005).
Recently, plant essential oils have shown antimicrobial and antiQS activity (Jaramillo-Colorado et al., 2011; Kerekes et al., 2013). Oregano essential oil (OEO) has been shown to possess the highest antimicrobial activity compared with other essential oils (Burt, 2004), and has been reported as a QS inhibitory extract (Nagy, 2010). OEO has been effective inhibiting the microbial growth of some food pathogens, such as Staphylococcus aureus, E. coli, Bacillus subtilis, and Saccharomyces cerevisiae at $0.625 \mu \mathrm{L} / \mathrm{mL}$ (Lv et al., 2011). Additionally, reduced Salmonella Newport inoculated in romaine and iceberg lettuce (0.7-4.8 log CFU/g), spinach (0.7-4.9 $\log$ CFU/g), and baby spinach (0.5-4.7 log CFU/g; Moore-Neibel et al., 2013). Carvacrol (one the main compounds of OEO) was effective inhibiting the growth and survival of L. monocytogenes, Aeromonas hydrophila, and Pseudomonas fluorescens showing MIC values of $0.6,0.6$, and $2.5 \mu \mathrm{L} / \mathrm{mL}$, respectively. Also the exposition of vegetables to these MICs caused the reduction in bacterial counts ( $<2 \log$ CFU/g; de Sousa et al., 2012). Additionally, it has been reported that carvacrol possess anti-QS activity against Chromobacterium violaceum at $<0.05 \mathrm{mM}$ (Ojo-Fakunle et al., 2013). 
Woertman (2014) reported that carvacrol at concentrations of 0.2 and $0.4 \mathrm{mM}$ reduced violacein production induced by QS of $C$. violaceum, without affecting bacterial viability. However, the high volatile character of the oil constituents complicates its uses in food matrices. In some cases food matrices do not allow the direct addition of this type of oils and other strategies must be evaluated.

Edible films could be useful to carry and stabilize volatile food additives (Min et al., 2005), and additionally act as barriers to oxygen permeability, moisture loss and lipid migration, maintain firmness and sensory attributes of the coated food (Oms-Oliu et al., 2008; Moalemiyan etal., 2012; Ferrari et al., 2013). Furthermore, pectin films added with cinnamon leaf oil and applied in fresh-cut peach and grapes decreased microbial growth and increased the antioxidant status of the treated fruit (Ayala-Zavala et al., 2013; Melgarejo-Flores et al., 2013). For this reason, the objective of this work was to evaluate the in vitro antibacterial and anti-QS activities of pectin films added with OEO, and their antimicrobial activity on coated shrimp and cucumber.

\section{MATERIALS AND METHODS PECTIN-OEO FILMS FORMULATION}

Pectin-OEO films were prepared using $3 \mathrm{~g}$ of citrus peel pectin ( $\geq 74 \%$ galacturonic acid and methoxy groups $\geq 6.7 \%$, Sigma, St. Louis, MO, USA), $0.99 \mathrm{~mL}$ of glycerol, and OEO (Lippia graveolens Kunt, ORE Procesadora de oregano silvestre, Chihuahua, Mexico) at different concentrations $(0,15.7,25.9$, and $36.1 \mathrm{mg} / \mathrm{mL})$, the components were dissolved in $100 \mathrm{~mL}$ of distilled water and homogenized for $15 \mathrm{~min}$ for edible films and coatings (AyalaZavala et al., 2013; Melgarejo-Flores et al., 2013). For films, $15 \mathrm{~mL}$ of each forming solution were poured in Petri dishes and dried at $60^{\circ} \mathrm{C}$ for $24 \mathrm{~h}$ : the dried films were separated from the dishes and used for antibacterial assays.

\section{ANTIBACTERIAL ACTIVITY OF OEO AND PECTIN-OEO FILMS AGAINST PATHOGENIC BACTERIA}

The antibacterial activity of the OEO and pectin-OEO films were tested against E. coli O157:H7 (ATCC 43890), S. enterica subsp. enterica serovar Choleraesuis (ATCC 7001), S. aureus (ATCC 6538), and L. monocytogenes (ATCC 7644). The inoculums were prepared using a $16 \mathrm{~h}$ culture adjusted by reference to an OD of 0.1 at $600 \mathrm{~nm}$ using a microplate reader (Fluostar Omega, BMG Labtech, Chicago, IL, USA), and further diluted with Mueller Hinton $(\mathrm{MH})$ broth to achieve approximately $1.25 \times 10^{8} \mathrm{CFU} / \mathrm{mL}$. Disk diffusion method was carried out to test the antibacterial activity of the films. With the aid of a moist sterile swab the inoculums were spread on plates of $\mathrm{MH}$ agar, left to dry for $15 \mathrm{~min}$ and incubated at $37^{\circ} \mathrm{C}$. Subsequently, pectin-OEO disks $(0.5 \mathrm{~cm}$ of diameter) were placed on the inoculated plates and incubated at $37^{\circ} \mathrm{C}$ for $24 \mathrm{~h}$. After incubation, the inhibition zones were measured to determine antibacterial activity, subtracting the film diameter $(\mathrm{mm})$. The resulting diameters of the inhibition zones were compared with control pectin disks without OEO. Broth microdilution method was developed to evaluate the antibacterial activity of OEO. Five $\mu \mathrm{L}$ of inoculums and $295 \mu \mathrm{L}$ of $\mathrm{MH}$ broth enriched with OEO (at concentrations ranging $0.1-1 \mathrm{mg} / \mathrm{mL}$ ) were taken and placed in sterile 96-well microplates (Costar 96), and incubated during $24 \mathrm{~h}$ at $37^{\circ} \mathrm{C}$. The lowest concentration of the OEO at which the tested bacteria did not show visible growth was taken as the minimal inhibitory concentration (MIC); additionally, the minimal bactericidal concentration (MBC) was determined as the lowest tested concentration of OEO to eliminate the inoculums; both MIC and MBC were expressed as $\mathrm{mg} / \mathrm{mL}$.

\section{INHIBITION OF C. violaceum QS BY THE PRESENCE OF OEO AND PECTIN-OEO FILMS}

C. violaceum (ATCC 12472) was used to determine the anti-QS effect of the oil and films. This bacterial model uses an intercellular communication response by the production of a purple pigment (violacein), induced by the presence of acyl homoserine lactones; analyzing the production of the pigment it is possible to evaluate the interference of a given substance in this process (Adonizio et al., 2006; Truchado et al., 2009). With this in mind, the inoculum of C. violaceum was grown aerobically in Luria-Bertani (LB) broth and incubated at $30^{\circ} \mathrm{C}$ for $18 \mathrm{~h}$ to obtain an OD of 0.1 at $600 \mathrm{~nm}$ $\left(1.25 \times 10^{8} \mathrm{CFU} / \mathrm{mL}\right)$.

\section{Disk diffusion assay}

LB agar plates were spread with $0.1 \mathrm{~mL}$ of C. violaceum inoculum, and then, disks of pectin-OEO films (0, 15.7, 25.9, and $36.1 \mathrm{mg} / \mathrm{mL})$, and the free oil impregnated in paper disks $(0$, $6.25,12.5$, and $25 \mathrm{mg} / \mathrm{mL}$ ) were placed on LB plates and incubated at $30^{\circ} \mathrm{C}$ during $24 \mathrm{~h}$. Growth and/or pigment inhibition around the disk was recorded after incubation following the methodology described by Zahin et al. (2010). C. violaceum growth inhibition (clear halo) was measured as radius ( $\mathrm{r} 1$ ) in $\mathrm{mm}$ while both growth and pigment inhibition (clear plus turbid halo) was measured as radius (r2) in $\mathrm{mm}$. The pigment (QS) inhibition was determined by subtracting bacterial growth inhibition radius ( $\mathrm{r} 1$ ) from radius ( $\mathrm{r} 2$ ) thus QS inhibition $=(\mathrm{r} 1-\mathrm{r} 2)$ to check the inhibition of violacein production around the disks. This experiment was carried out by triplicate.

\section{Quantification of pigment production}

The violacein production of $C$. violaceum exposed to $\mathrm{OEO}$ and pectin-OEO films was quantified. Ten $\mathrm{mL}$ of LB broth containing sub-inhibitory concentrations of OEO $(0.0156,0.312,0.625$, and $0.125 \mathrm{mg} / \mathrm{mL})$ and pectin-OEO films $(0.25,0.5,1$, and $2 \mathrm{mg} / \mathrm{mL}$ of pectin films added with $15.7,25.9$, and $36.1 \mathrm{mg} / \mathrm{mL}$ of $O E O)$ were inoculated and incubated at $30^{\circ} \mathrm{C}$ for $24 \mathrm{~h}$. The quantification of violacein production was carried out following the protocol described by Choo etal. (2006), where $1 \mathrm{~mL}$ of culture from each sample was centrifuged at $13,000 \mathrm{rpm}$ for $10 \mathrm{~min}$ to precipitate the insoluble violacein. Then, the culture supernatant was discarded, and the pellet was solubilized in $1 \mathrm{~mL}$ of dimethylsulfoxide, vortexed until the violacein was extracted, and centrifuged at 13,000 rpm for $10 \mathrm{~min}$ to remove cells. OD of each violacein containing supernatant was measured at $585 \mathrm{~nm}$, results were expressed as percentage of violacein production. The control of each experiment was LB medium without OEO or films; pigment production of control sample was set as $100 \%$. LB plus pectin without OEO was confirmed as negative control. The viability of C. violaceum was analyzed taking $1 \mathrm{~mL}$ serially diluted of each treatment (OEO and pectin-OEO films), and spread onto LB agar 
plates at $30^{\circ} \mathrm{C}$ for $24 \mathrm{~h}$. The bacteria counts were expressed as $\log$ $\mathrm{CFU} / \mathrm{mL}$, this assay was performed by triplicate.

\section{ANTIMICROBIAL ACTIVITY OF PECTIN-OEO COATINGS ON SHRIMPS AND CUCUMBERS}

Fresh shrimps (Litopenaeus vannamei) and cucumbers (Cucumis sativus L.) were selected free from signs of decay from local market. Shrimps and cucumber slices (slices of $0.5 \mathrm{~cm}$ of cucumber) were coated by immersion during $2 \mathrm{~min}$, in pectin-OEO solutions $(0$, $15.7,25.9$, and $36.1 \mathrm{mg} / \mathrm{mL}$ ) prepared as described before, the excess of the coating solutions was drained. The coated food was let to dry at $25^{\circ} \mathrm{C}$ during $30 \mathrm{~min}$, and then packed in polypropylene trays and stored at $4^{\circ} \mathrm{C}$ during 15 days. Total coliforms, yeast and molds counts of the coated food were recorded according to the U.S. Food and Drug Administration Bacteriological Analytical Manual methodology (FDA, 2014). The coated foods (10 g) were diluted (1:9) in a solution containing $0.1 \mathrm{~g} / 100 \mathrm{~mL}$ of peptone and $0.5 \mathrm{~g} / 100 \mathrm{~mL}$ of sodium chloride and homogenized for $1 \mathrm{~min}$. Subsequently, 10-fold dilutions were also made in this diluent. Each dilution was plated in triplicate in violet red bile and potato dextrose agars, for total coliforms, yeast and molds, respectively. Results were expressed as log CFU/g of the sample.

\section{STATISTICAL ANALYSIS}

A completely randomized experimental design was applied to all experiments. The antimicrobial effect of OEO and pectin-OEO films (MICs and diameter of inhibition zones against E. coli, S. Choleraesuis, L monocytogenes, and S. aureus) and the QS inhibition (inhibition radios, pigment production, and viability of $C$. violaceum) were evaluated. In addition, the effect of pectin-OEO coatings on shrimp and cucumber slices was tested. An analysis of variance (ANOVA) was performed $(p \leq 0.05)$ to estimate significant differences between the treatments, and Tukey's mean test was used for comparison ( $p \leq 0.05)$ using the NCSS 2007.

\section{RESULTS}

\section{ANTIMICROBIAL ACTIVITY OF OEO AND PECTIN-OEO FILMS}

Table 1 shows the antibacterial activity of OEO against pathogenic bacteria. OEO was effective to inhibit bacterial growth at a MIC of $0.24 \mathrm{mg} / \mathrm{mL}$ for all tested bacteria; and showed MBC of $0.24,0.24,0.48$, and $0.24 \mathrm{mg} / \mathrm{mL}$ against E. coli $\mathrm{O} 157: \mathrm{H} 7$, S. Choleraesuis, S. aureus, and L. monocytogenes, respectively. Table 2 shows that pectin-film incorporated with 36.1 and $25.9 \mathrm{mg} / \mathrm{mL}$ of OEO were more effective, showing inhibition zones with diameters of 16.3 and $15.2 \mathrm{~mm}$ for E. coli O157:H7; 18.1 and $24.2 \mathrm{~mm}$ for $S$. Choleraesuis; 20.8 and $20.3 \mathrm{~mm}$ for S. aureus; 21.3 and $19.3 \mathrm{~mm}$ for L. monocytogenes, respectively. The pectin-OEO film $(15.7 \mathrm{mg} / \mathrm{mL})$ was effective against $E$. coli O157:H7 (9.3 mm), S. aureus $(9.7 \mathrm{~mm})$, and L. monocytogenes $(9.2 \mathrm{~mm})$, but no inhibition zones were observed for $S$. Choleraesuis.

\section{INHIBITION OF C. Violaceum CELL TO CELL COMMUNICATION EXPOSED TO OEO AND PECTIN-OEO FILMS}

Table 3 shows the effectiveness of different concentrations of OEO and pectin-OEO films to inhibit QS of C. violaceum. According to inhibition radios, both OEO and pectin-OEO films exhibited
Table 1 | Minimum inhibitory concentration (MIC; $\mathrm{mg} / \mathrm{mL}$ ) and minimum bactericidal concentration (MBC; $\mathrm{mg} / \mathrm{mL}$ ) of $O E O$ against pathogenic bacteria.

\begin{tabular}{lllll}
\hline Escherichia & $\begin{array}{l}\text { Salmonella } \\
\text { Cholerae- } \\
\text { suis }\end{array}$ & $\begin{array}{l}\text { Staphylococcus } \\
\text { aureus }\end{array}$ & $\begin{array}{l}\text { Listeria } \\
\text { monocyto- } \\
\text { genes }\end{array}$ \\
\hline MIC & 0.24 & 0.24 & 0.24 & 0.24 \\
MBC & 0.24 & 0.24 & 0.48 & 0.24 \\
\hline
\end{tabular}

Values are mean of three replicates.

concentration dependent anti-QS activity. OEO tested at 6.25 and $12.5 \mathrm{mg} / \mathrm{mL}$ exerted a significant pigment inhibition without affecting $C$. violaceum growth. At elevated concentration as $25 \mathrm{mg} / \mathrm{mL}$, this extract demonstrated antibacterial activity along with the anti-QS activity (Table 3). With regards to film plus OEO, exerted a higher pigment inhibition when compared with free OEO. The highest concentration of OEO enriched film tested, $36.1 \mathrm{mg} / \mathrm{mL}$, inhibited bacterial growth along with pigment production. These differences may be due to the presence of higher concentrations of OEO in the films.

Figure 1A shows the capacity of OEO to inhibit violacein production from $C$. violaceum exposed to different concentrations $(0.0156,0.0312,0.0625$, and $0.125 \mathrm{mg} / \mathrm{mL})$. To evaluate whether the inhibition of violacein production owed to the QS mechanism inhibition or to microbial growth reduction, the $C$. violaceum concentration was also determined. An inverse relationship between pigment production and the applied OEO concentrations was noticed, compared with control samples. All the tested OEO concentrations showed a significant drop in violacein production even the lowest one $(0.0156 \mathrm{mg} / \mathrm{mL})$ which reduced pigment production by more than $50 \%$. In addition, the cell viability (Figure 1B) of $C$. violaceum was not affected at concentrations of $0.156,0.032$, and 0.0625 ; only the highest concentration $(0.125 \mathrm{mg} / \mathrm{mL})$ inhibited the growth reducing the bacterial counts ( $7 \log \mathrm{CFU} / \mathrm{mL}$ ) after the incubation period. Similarly, pectin-OEO films showed a significant inhibition of violacein production (Figure 2) compared with controls. All pectin films added with $15.7,25.9$, and $36.1 \mathrm{mg} / \mathrm{mL}$ of OEO were tested at concentrations of $0.25,0.5,1$, and $2 \mathrm{mg} / \mathrm{mL}$, and all of them were effective reducing the violacein production. No differences were observed among the concentrations of $0.5,1$, and $2 \mathrm{mg} / \mathrm{mL}$ of pectin films added with $15.7,25.9$, and $36.1 \mathrm{mg} / \mathrm{mL}$ of OEO showing the highest inhibition percent (more than 90\%) of the violacein production. With respect to the effect of the pectinOEO films on the C. violaceum viability (Figure 2B), it was observed that for all the pectin-OEO films the concentration of $0.25 \mathrm{mg} / \mathrm{mL}$ inhibited QS without affecting the cellular viability, in addition, the concentrations of $0.5,1$, and $2 \mathrm{mg} / \mathrm{mL}$ of the pectin films added with $15.7 \mathrm{mg} / \mathrm{mL}$ of OEO did not affect cellular viability and affected violacein production. On the other hand, the inhibition on pigment production exerted by 25.9 and $36.1 \mathrm{mg} / \mathrm{mL}$ pectin-OEO films applied at $\geq 0.5 \mathrm{mg} / \mathrm{mL}$ showed significant $(p<0.05)$ antibacterial effect instead of a blockage of QS mechanism. 
Table 2 | Inhibition zones of pectin-OEO films against pathogenic bacteria.

\begin{tabular}{lllll}
\hline $\begin{array}{l}\text { OEO in pectin } \\
\text { films }(\mathbf{m g} / \mathbf{m L})\end{array}$ & E. coli & \multicolumn{2}{c}{ Inhibition zone diameter (mm) } \\
\cline { 2 - 5 } & 0 & S. Choleraesuis & S. aureus & L. monocytogenes \\
\hline 0 & $9.3 \pm 0.11$ & 0 & 0 & 0 \\
15.7 & $16.3 \pm 0.27$ & 0 & $9.7 \pm 0.057$ & $9.2 \pm 0.04$ \\
25.9 & $15.2 \pm 0.052$ & $18.1 \pm 0.29$ & $20.8 \pm 0.08$ & $21.3 \pm 0.24$ \\
36.1 & $24.2 \pm 0.18$ & $20.3 \pm 0.06$ & $19.3 \pm 0.104$ \\
\hline
\end{tabular}

Values are mean $\pm S D$ of three replicates.

Table 3 | Anti-OS activity of OEO and pectin-OEO films by disk diffusion method using $C$. violaceum as indicator strain.

\begin{tabular}{|c|c|c|c|c|}
\hline & \multirow[b]{2}{*}{$\begin{array}{l}\text { Concentration } \\
(\mathrm{mg} / \mathrm{mL})\end{array}$} & \multicolumn{3}{|c|}{ Inhibition zones against $C$. violaceum (radios in $\mathrm{mm}$ ) } \\
\hline & & $\begin{array}{l}\text { Growth } \\
\text { inhibition ( } r 1)\end{array}$ & $\begin{array}{l}\text { Growth + } \\
\text { pigment } \\
\text { inhibition (r2) }\end{array}$ & $\begin{array}{l}\text { QS inhibition } \\
\text { (r2-r1) }\end{array}$ \\
\hline \multirow[t]{3}{*}{ OEO } & 0 & ND & ND & ND \\
\hline & 12.5 & ND & $5.6 \pm 0.29$ & $5.6 \pm 0.29$ \\
\hline & 25 & $5.0 \pm 0.00$ & $10.8 \pm 1.04$ & $5.8 \pm 1.04$ \\
\hline \multirow[t]{3}{*}{ Pectin-OEO film } & 0 & ND & ND & ND \\
\hline & 15.7 & ND & $25.6 \pm 0.76$ & $25.6 \pm 0.76$ \\
\hline & 25.9 & ND & $30.5 \pm 2.78$ & $30.5 \pm 2.78$ \\
\hline
\end{tabular}

Values of radios are mean $\pm S D$ of three replicates. $N D$, not detected inhibition.

\section{EFFECT OF PECTIN-OEO COATINGS ON THE MICROBIAL GROWTH OF SHRIMP AND CUCUMBER}

Figure 3 shows the effectiveness of pectin-OEO coatings to reduce the growth of total coliforms, yeast and molds of shrimp and sliced cucumber stored at $4^{\circ} \mathrm{C}$ during 15 days. Pectin-OEO coatings of $15.7,25.9$, and $36.1 \mathrm{mg} / \mathrm{mL}$ were effective reducing 1.39 $\log$ CFU/g of total coliforms with respect to control fruit at day 0 . All treatments showed an increment in total coliforms load during the storage time; however, the pectin-OEO coated shrimp showed lower load during the storage (Figure 3A). Similarly, the pectinOEO coated shrimp (Figure 3B) caused a general reduction of total yeast and molds of $1.4 \log \mathrm{CFU} / \mathrm{g}$ with respect to control and pectin films (2.39 log CFU/g) and this difference remained throughout the storage time. The effect of pectin-OEO coatings on the microbial load of fresh-cut cucumber (Figures 3C,D) was similar to that observed for shrimps. The three concentrations of pectin-OEO coatings maintained the total coliforms at $1 \mathrm{log}$ CFU/g during the storage time $(\mathrm{C})$ compared with the control and pectin coating that showed 7.28 and $6.34 \log \mathrm{CFU} / \mathrm{g}$ at the end of the storage. Similarly to the effect observed in shrimp, total yeast and molds load of sliced cucumber coated with the pectin-OEO formulations (Figure 3D) maintained the load at $1 \log \mathrm{CFU} / \mathrm{g}$ compared with control and pectin coated fruit that shown 3.19 and $4.07 \log \mathrm{CFU} / \mathrm{g}$ throughout the storage. These results demonstrated that the incorporation of OEO in pectin coatings reduced the microbial growth of the studied food, showing a protective effect over the storage time.

\section{DISCUSSION}

Oregano essential oil antimicrobial activity has been widely reported in the literature against some foodborne pathogens. In our study, the MIC for all tested bacteria was different to those reported in previous studies (Burt and Reinders, 2003). OEO from Origanum vulgare presented a bactericidal effect against E. coli O157:H7 when applied at $0.57 \mathrm{mg} / \mathrm{mL}$ (Burt and Reinders, 2003). On the other hand, Lambert et al. (2001) reported the OEO MIC as $0.575 \mathrm{mg} / \mathrm{mL}$ against $S$. aureus. The differences found with previous works could be attributed to several factors like development stage, variety, ecological conditions, and other plant factors (Özcan and Erkmen, 2001). With respect to inhibition of pectin films added with OEO, other studies shown higher inhibition zones as reported by Du et al. (2009) which evaluated the antimicrobial activity of OEO in pectin films against E. coli O157:H7, S. enterica and $L$. monocytogenes. They found that pectin film incorporated with OEO presented a high antimicrobial activity. In addition, main components of OEO such as carvacrol added to pectin films 


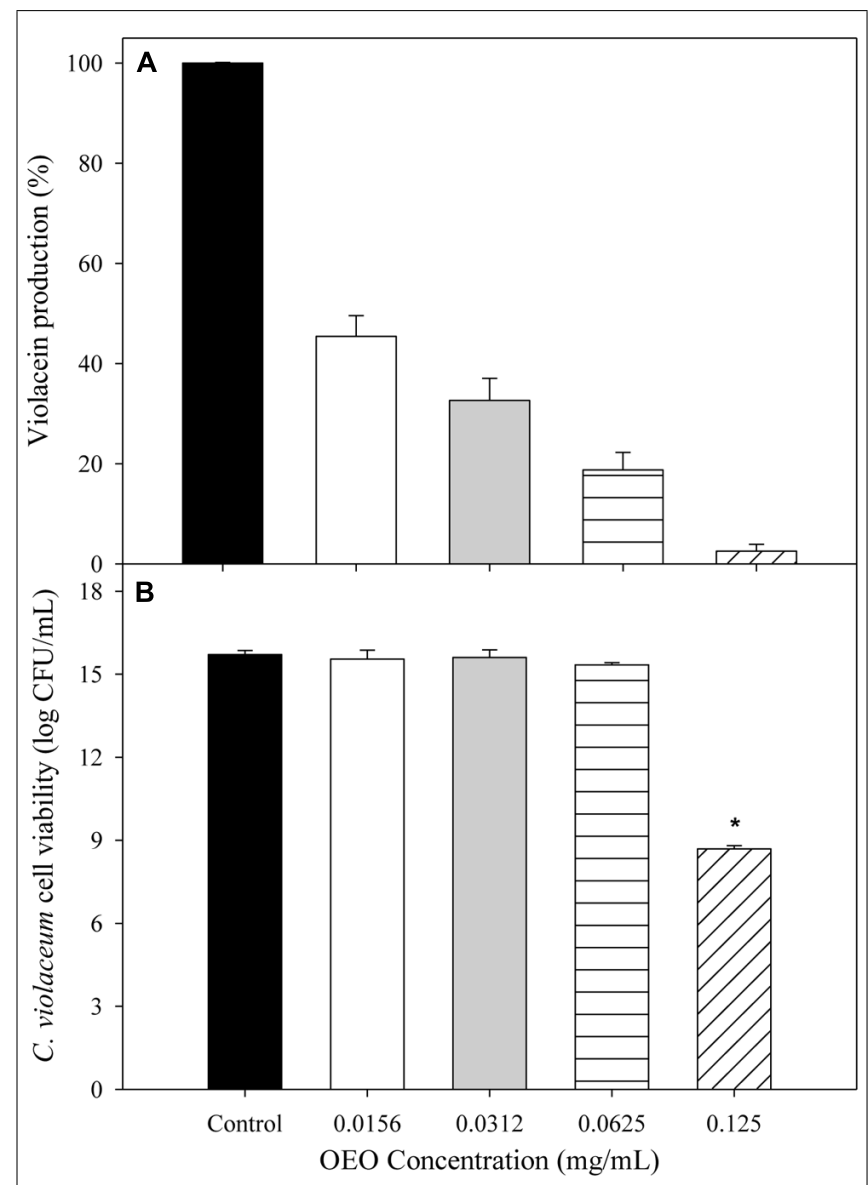

FIGURE 1 | (A) Inhibition of violacein production of $C$. violaceum exposed to $\mathrm{OEO}$ at different concentrations. (B) $C$. violaceum viability after incubation in LB broth enriched with different concentrations of OEO. * Significantly different when compared to control $(p<0.05)$.

presented antimicrobial activity against E. coli O157:H7 (Du et al., 2008). On the other hand, Seydim and Sarikus (2006) tested whey protein films added with $\mathrm{OEO}$ at $2 \%$ and showed inhibition zones of 49.1, 65.4, 62.0, 61.4, and $34.4 \mathrm{~mm}$ against E. coli O157:H7, S. aureus, S. enteritidis, L. monocytogenes, and Lactobacillus plantarum, respectively. These higher values can be an indicative of the effect of the polymer matrices used in the film formulation. The antibacterial efficacy of the OEO in different food matrices reflects its potential uses in the food industry against pathogenic bacteria.

Some studies have demonstrated the potential use of different plant extracts with anti-QS activity (Alvarez et al., 2012). Loss of purple pigment in C. violaceum is an indicative of QS inhibition by the bioactive products. The results obtained in this study reflects the potential of OEO free or incorporated within pectin films at low concentrations as promising QS inhibitors, considering that were able to interrupt intercellular communication inhibiting the violacein production without affecting growth inhibition (Choo et al., 2006). The observed anti-QS effect of the OEO could be attributed to its bioactive constituents such as carvacrol. Vattem et al. (2007) reported that carvacrol reduced violacein production of $C$. violaceum up

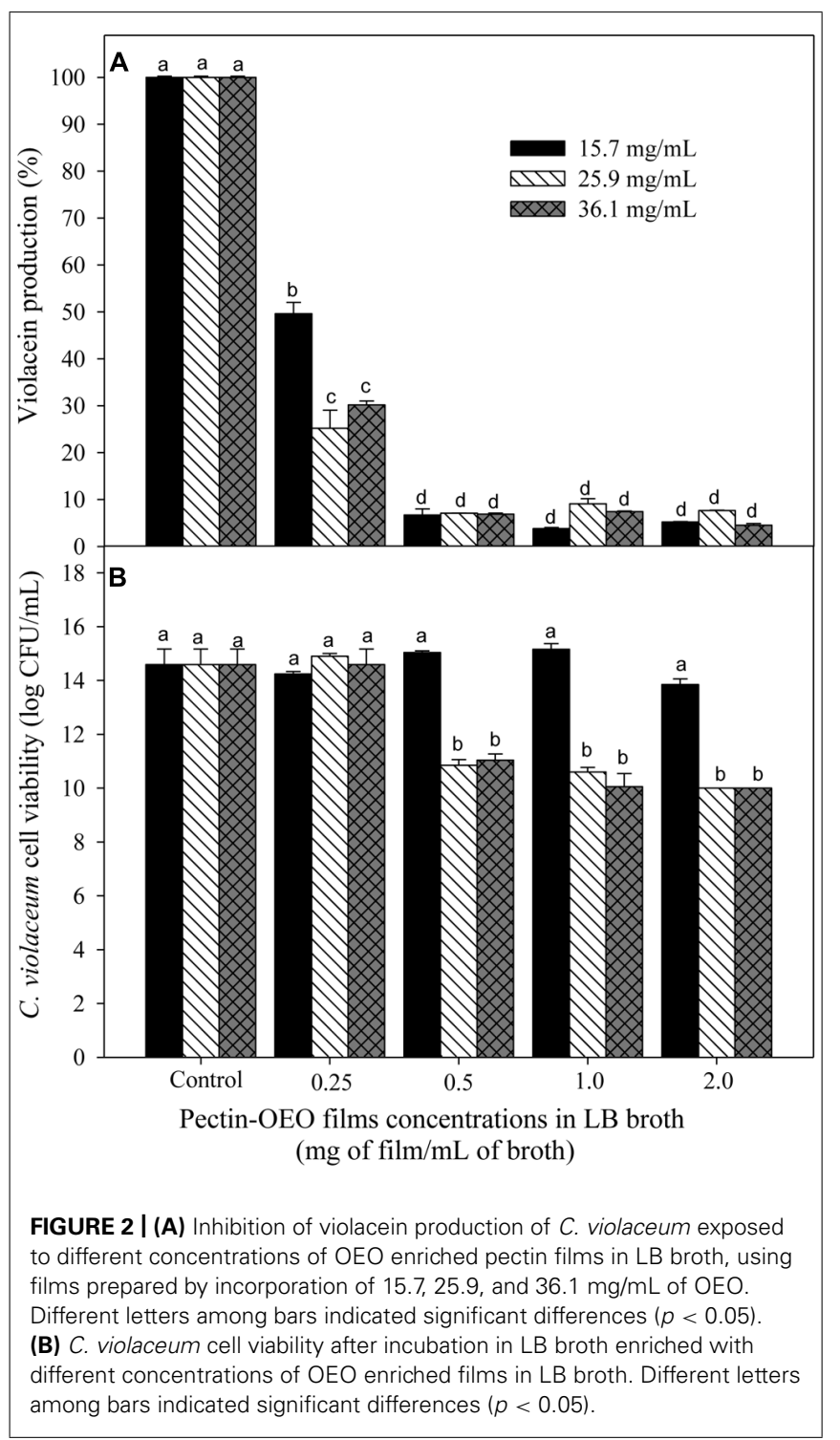

to $8 \mathrm{mM}$ without affecting viability. These authors associated the pigment inhibition of carvacrol to the reduction in gene expression coding for the synthesis of acyl homoserine lactones, as described before, it is a key signaling molecule in the QS. Different mechanisms have been proposed to explain the interference of QS depending processes induced by natural products: (i) inhibition of signal molecule biosynthesis or acyl homoserine lactone signal reception (Rasmussen etal., 2005; Vattem et al., 2007), and the ii) enzymatic inactivation and biodegradation of QS molecules (Defoirdt et al., 2004). Gao et al. (2003), reported that the interruption of bacterial QS by plant extracts has been barely studied, and highlighted its importance as controller agents for microbial pathogenesis. These findings reflects the potential of free $\mathrm{OEO}$ or incorporated within pectin films at low concentrations as promising QS inhibitors, considering that were able to interrupt intercellular communication inhibiting the violacein production without causing growth inhibition (Choo et al., 2006). 


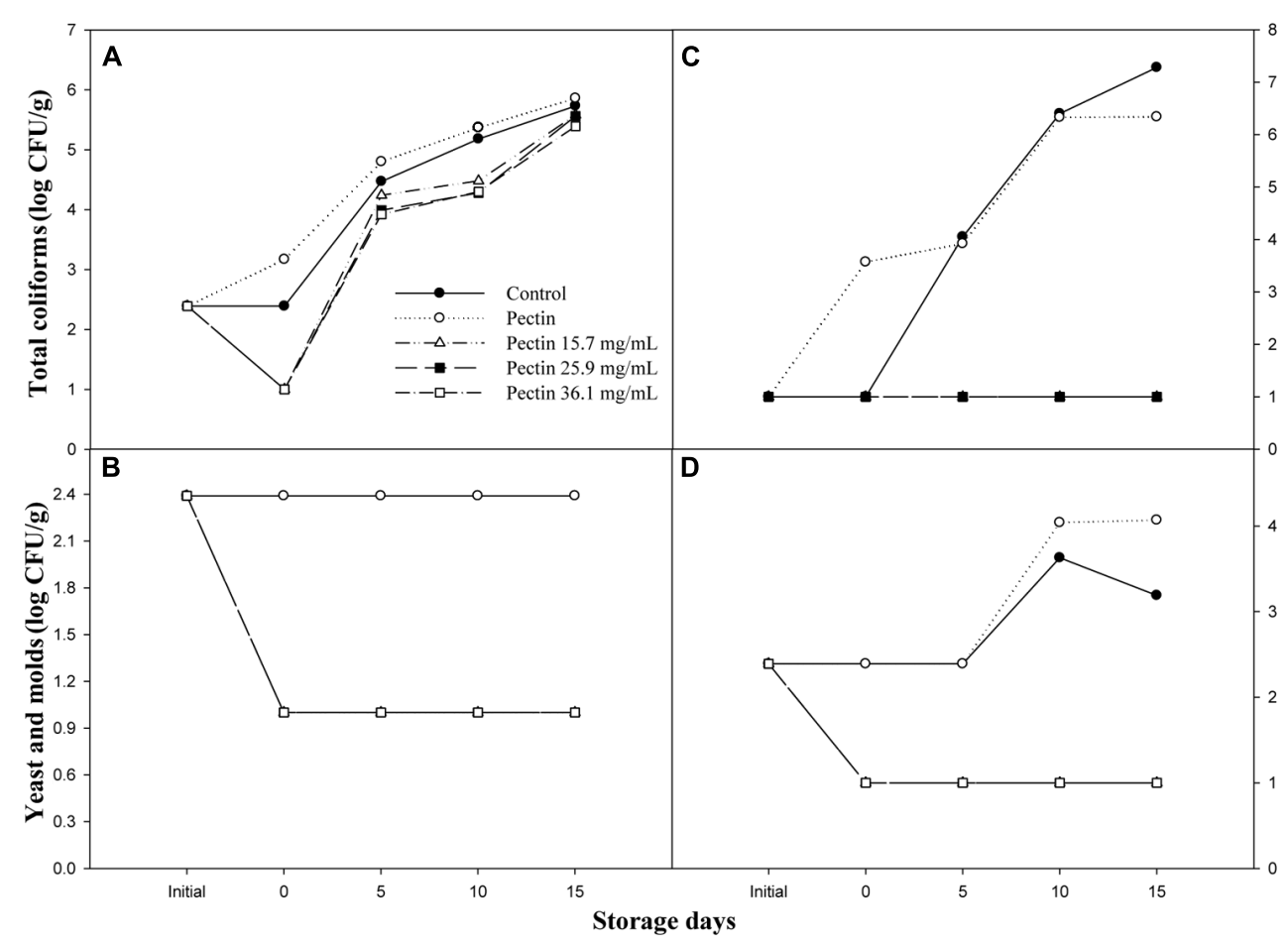

FIGURE 3 | Effect of OEO on the microbial load (log CFU/g), (A) total coliforms and (B) yeast and molds in shrimp; (C) total coliforms and (D) yeast and molds in sliced cucumber throughout 15 days of storage at $4^{\circ} \mathrm{C}$.

Previous studies have been reported the effectiveness of the application of coatings enriched with essential oils in foods (Ravishankar et al., 2009). Pectin films enriched with carvacrol at $3 \%$ showed a high reduction against S. enterica and E. coli O157:H7 (4.3-6.8 log CFU/g) inoculated in chicken breasts (Ravishankar et al., 2009). In another study, $1 \%$ of OEO incorporated into a calcium caseinate WPI-carboxymethyl cellulose film was found to be effective against E. coli O157:H7 and Pseudomonas spp. on the surface of beef muscle pieces (Oussalah et al., 2004). On the other hand, pectin coatings added with other essential oils to prevent deterioration of different vegetable tissues have been widely used; e.g., Melgarejo-Flores et al. (2013) reported a significant inhibition of microbial growth of grapes after application of pectin coatings with cinnamon leaf oil at concentration of $36.1 \mathrm{mg} / \mathrm{mL}$, compared controls and coated grapes only with pectin, which showed the highest spoilage after 15 days at $10^{\circ} \mathrm{C}$. Similarly, Ayala-Zavala etal. (2013), applied the same coatings on fresh-cut peaches and observed growth inhibition of $E$. coli O157:H7, S. aureus, and L. monocytogenes at a concentration of $36.1 \mathrm{mg}$ of cinnamon leaf oil per $\mathrm{mL}$ of pectin solution (30 mg/mL).

\section{CONCLUSION}

Oregano essential oil incorporated within edible films or coatings showed an inhibitory effect on the QS of C. violaceum, inhibiting the intercellular communication process. In addition, the pectin-OEO mixtures showed antibacterial effect against food pathogenic and spoilage microorganisms. These results can be useful to study the effect of the treatments on the pathogenesis of the studied microorganisms. Therefore, it is highlighted the potential of the studied pectin-OEO edible films and coatings to be used as antimicrobial agent to assure food safety and quality.

\section{REFERENCES}

Adonizio, A. L., Downum, K., Bennett, B. C., and Mathee, K. (2006). Anti-quorum sensing activity of medicinal plants in southern Florida. J. Ethnopharmacol. 105, 427-435. doi: 10.1016/j.jep.2005.11.025

Alvarez, M. V., Moreira, M. R., and Ponce, A. (2012). Antiquorum sensing and antimicrobial activity of natural agents with potential use in food. J. Food Safety 32, 379-387. doi: 10.1111/j.1745-4565.2012.00390.x

Ayala-Zavala, J. F., Silva-Espinoza, B., Cruz-Valenzuela, M., Leyva, J., OrtegaRamírez, L., Carrazco-Lugo, D., et al. (2013). Pectin-cinnamon leaf oil coatings add antioxidant and antibacterial properties to fresh-cut peach. Flavour Frag. J. 28, 39-45. doi: 10.1002/ffj.3125

Burt, S. (2004). Essential oils: their antibacterial properties and potential applications in foods-a review. Int. J. Food Microbiol. 94, 223-253. doi: 10.1016/j.ijfoodmicro.2004.03.022

Burt, S. A., and Reinders, R. D. (2003). Antibacterial activity of selected plant essential oils against Escherichia coli O157:H7. Lett. Appl. Microbiol. 36, 162-167. doi: 10.1046/j.1472-765X.2003.01285.x

CDC. (2014). Germs (and some foods) Responsible for Most Foodborne Illness [Online]. Available at: http://www.cdc.gov/foodsafety/cdc-and-food-safety.html \#top [Accessed September 15, 2014].

Choo, J., Rukayadi, Y., and Hwang, J. (2006). Inhibition of bacterial quorum sensing by vanilla extract. Lett. Appl. Microbiol. 42, 637-641.

de Sousa, J. P., de Azerêdo, G. A., de Araújo Torres, R., da Silva Vasconcelos, M. A., da Conceição, M. L., and de Souza, E. L. (2012). Synergies of carvacrol and 1,8-cineole to inhibit bacteria associated with minimally processed vegetables. Int. J. Food Microbiol. 154, 145-151. doi: 10.1016/j.ijfoodmicro.2011. 12.026 
Defoirdt, T., Boon, N., Bossier, P., and Verstraete, W. (2004). Disruption of bacterial quorum sensing: an unexplored strategy to fight infections in aquaculture. Aquaculture 240, 69-88. doi: 10.1016/j.aquaculture.2004.06.031

Dong, Y.-H., and Zhang, L.-H. (2005). Quorum sensing and quorum-quenching enzymes. J. Microbiol. 43, 101-109. doi: 10.3390/ijms140917477

Du, W.-X., Olsen, C. W., Avena-Bustillos, R. J., Mchugh, T. H., Levin, C. E., and Friedman, M. (2008). Storage stability and antibacterial activity against Escherichia coli O157:H7 of carvacrol in edible apple films made by two different casting methods. J. Agr. Food Chem. 56, 3082-3088. doi: 10.1021/jf703629s

Du, W. X., Olsen, C. W., Avena-Bustillos, R. J., Mchugh, T. H., Levin, C. E., and Friedman, M. (2009). Effects of allspice, cinnamon, and clove bud essential oils in edible apple films on physical properties and antimicrobial activities. J. Food Sci. 74, M372-M378. doi: 10.1111/j.1750-3841.2009.01282.x

FDA. (2014). Bacteriological Analytical Manual. Available at: http://www.cfsan.fda. gov/ ebam/bam-toc.html [accessed September 1, 2014].

Ferrari, C. C., Sarantópoulos, C. I., Carmello-Guerreiro, S. M., and Hubinger, M. D. (2013). Effect of osmotic dehydration and pectin edible coatings on quality and shelf life of fresh-cut melon. Food Bioprocess Tech. 6, 80-91. doi: 10.1007/s11947011-0704-6

Gao, M., Teplitski, M., Robinson, J. B., and Bauer, W. D. (2003). Production of substances by Medicago truncatula that affect bacterial quorum sensing. Mol. Plant Microbe Interact. 16, 827-834. doi: 10.1094/MPMI.2003. 16.9.827

Jaramillo-Colorado, B., Olivero-Verbel, J., Stashenko, E. E., Wagner-Döbler, I., and Kunze, B. (2011). Anti-quorum sensing activity of essential oils from Colombian plants. Nat. Prod. Res. 26, 1075-1086. doi: 10.1080/14786419.2011.5 57376

Kerekes, E. B., Deák, É., Takó, M., Tserennadmid, R., Petkovits, T., Vágvölgyi, C., et al. (2013). Anti-biofilm forming and anti-quorum sensing activity of selected essential oils and their main components on food-related microorganisms. J. Appl. Microbiol. 115, 933-942. doi: 10.1111/jam.12289

Lambert, R. J. W., Skandamis, P. N., Coote, P. J., and Nychas, G. J. E. (2001). A study of the minimum inhibitory concentration and mode of action of oregano essential oil, thymol and carvacrol. J. Appl. Microbiol. 91, 453-462. doi: 10.1046/j.13652672.2001.01428.x

Lv, F., Liang, H., Yuan, Q., and Li, C. (2011). In vitro antimicrobial effects and mechanism of action of selected plant essential oil combinations against four food-related microorganisms. Food Res. Int. 44, 3057-3064. doi: 10.1016/j.foodres.2011.07.030

Melgarejo-Flores, B. G., Ortega-Ramírez, L. A., Silva-Espinoza, B. A., GonzálezAguilar, G. A., Miranda, M. R. A., and Ayala-Zavala, J. F. (2013). Antifungal protection and antioxidant enhancement of table grapes treated with emulsions, vapors, and coatings of cinnamon leaf oil. Postharvest Biol. Tec. 86, 321-328. doi: 10.1016/j.postharvbio.2013.07.027

Miller, M. B., and Bassler, B. L. (2001). Quorum sensing in bacteria. Annu. Rev. Microbiol. 55, 165-199. doi: 10.1146/annurev.micro.55.1.165

Min, S., Harris, L. J., and Krochta, J. M. (2005). Antimicrobial effects of lactoferrin, lysozyme, and the lactoperoxidase system and edible whey protein films incorporating the lactoperoxidase system against Salmonella enterica and Escherichia coli O157: H7. J. Food Sci. 70, m332-m338. doi: 10.1111/j.1365-2621.2005. tb11476.x

Moalemiyan, M., Ramaswamy, H. S., and Maftoonazad, N. (2012). Pectin-based edible coating for shelf-life extension of ataulfo mango. J. Food Process Eng. 35, 572-600. doi: 10.1111/j.1745-4530.2010.00609.x

Moore-Neibel, K., Gerber, C., Patel, J., Friedman, M., Jaroni, D., and Ravishankar, S. (2013). Antimicrobial activity of oregano oil against antibiotic-resistant Salmonella enterica on organic leafy greens at varying exposure times and storage temperatures. Food Microbiol. 34, 123-129. doi: 10.1016/j.fm.2012.12.001

Nagy, M. M. (2010). Quorum Sensing Inhibitory Activities of Various Folk-Medicinal Plants and the Thyme-Tetracycline Effect. Ph.D. thesis, Georgia State University, Atlanta, GA.

Nazzaro, F., Fratianni, F., De Martino, L., Coppola, R., and De Feo, V. (2013). Effect of essential oils on pathogenic bacteria. Pharmaceuticals 6, 1451-1474. doi: 10.3390/ph6121451

Ojo-Fakunle, V. T., Woertman, J., Veldhuizen, E. J., and Burt, S. A. (2013). Sub-lethal concentrations of carvacrol (from oregano) inhibit bacterial quorum sensing and formation of biofilms. Planta Med. 79, SL51. doi: 10.1055/s-00331351877
Oms-Oliu, G., Soliva-Fortuny, R., and Martín-Belloso, O. (2008). Using polysaccharide-based edible coatings to enhance quality and antioxidant properties of fresh-cut melon. LWT-Food Sci. Technol. 41, 1862-1870. doi: 10.1016/j.lwt.2008.01.007

Oussalah, M., Caillet, S., Salmiéri, S., Saucier, L., and Lacroix, M. (2004). Antimicrobial and antioxidant effects of milk protein-based film containing essential oils for the preservation of whole beef muscle. J. Agr. Food Chem. 52, 5598-5605.

Özcan, M., and Erkmen, O. (2001). Antimicrobial activity of the essential oils of Turkish plant spices. Eur. Food Res. Technol. 212, 658-660. doi: $10.1007 / \mathrm{s} 002170100310$

Rasch, M., Andersen, J. B., Nielsen, K. F., Flodgaard, L. R., Christensen, H., Givskov, M., et al. (2005). Involvement of bacterial quorum-sensing signals in spoilage of bean sprouts. Appl. Environ. Microb. 71, 3321-3330. doi: 10.1128/AEM.71.6.3321-3330.2005

Rasmussen, T. B., Bjarnsholt, T., Skindersoe, M. E., Hentzer, M., Kristoffersen, P., Köte, M., et al. (2005). Screening for quorum-sensing inhibitors (QSI) by use of a novel genetic system, the QSI selector. J. Bacteriol. 187, 1799-1814. doi: 10.1128/AEM.71.6.3321-3330.2005

Ravishankar, S., Zhu, L. B., Olsen, C. W., Mchugh, T. H., and Friedman, A. (2009). Edible apple film wraps containing plant antimicrobials inactivate foodborne pathogens on meat and poultry products. J. Food Sci. 74, M440-M445. doi: 10.1111/j.1750-3841.2009.01320.x

Scallan, E., Hoekstra, R. M., Angulo, F. J., Tauxe, R. V., Widdowson, M.-A., Roy, S. L., etal. (2011). Foodborne illness acquired in the United States-major pathogens. Emerg. Infect. Dis. 17, 7-15. doi: 10.3201/eid1701. P11101

Seydim, A. C., and Sarikus, G. (2006). Antimicrobial activity of whey protein based edible films incorporated with oregano, rosemary and garlic essential oils. Food Res. Int. 39, 639-644. doi: 10.1016/j.foodres.2006.01.013

Truchado, P., López-Gálvez, F., Gil, M., Tomás-Barberán, F., and Allende, A. (2009). Quorum sensing inhibitory and antimicrobial activities of honeys and the relationship with individual phenolics. Food Chem. 115, 1337-1344. doi: 10.1016/j.foodres.2006.01.013

Truchado, P., Tomás-Barberán, F. A., Larrosa, M., and Allende, A. (2012). Food phytochemicals act as Quorum Sensing inhibitors reducing production and/or degrading autoinducers of Yersinia enterocolitica and Erwinia carotovora. Food Control 24, 78-85. doi: 10.1016/j.foodcont.2011.09.006

Vattem, D., Mihalik, K., Crixell, S., and Mclean, R. (2007). Dietary phytochemicals as quorum sensing inhibitors. Fitoterapia 78, 302-310. doi: 10.1016/j.fitote.2007.03.009

Woertman, J. (2014). Effect of carvacrol on mature biofilms and bacterial quorum sensing [Online]. Available:http://dspace.library.uu.nl/handle/1874/289409 [Accessed October 24, 2014].

Zahin, M., Hasan, S., Aqil, F., Khan, M. S. A., Husain, F. M., and Ahmad, I. (2010). Screening of certain medicinal plants from India for their anti-quorum sensing activity. Indian J. Exp. Biol. 48, 1219-1224.

Conflict of Interest Statement: The authors declare that the research was conducted in the absence of any commercial or financial relationships that could be construed as a potential conflict of interest.

Received: 29 October 2014; paper pending published: 12 November 2014; accepted: 25 November 2014; published online: 17 December 2014.

Citation: Alvarez MV, Ortega-Ramirez LA, Gutierrez-Pacheco MM, BernalMercado AT, Rodriguez-Garcia I, Gonzalez-Aguilar GA, Ponce A, Moreira MdR, Roura SI and Ayala-Zavala JF (2014) Oregano essential oil-pectin edible films as anti-quorum sensing and food antimicrobial agents. Front. Microbiol. 5:699. doi: 10.3389/fmicb.2014.00699

This article was submitted to Antimicrobials, Resistance and Chemotherapy, a section of the journal Frontiers in Microbiology.

Copyright (c) 2014 Alvarez, Ortega-Ramirez, Gutierrez-Pacheco, Bernal-Mercado, Rodriguez-Garcia, Gonzalez-Aguilar, Ponce, Moreira, Roura and Ayala-Zavala. This is an open-access article distributed under the terms of the Creative Commons Attribution License (CC BY). The use, distribution or reproduction in other forums is permitted, provided the original author(s) or licensor are credited and that the original publication in this journal is cited, in accordance with accepted academic practice. No use, distribution or reproduction is permitted which does not comply with these terms. 